\title{
Properties of Sugar Cane Bagasse to Use in OSB
}

\author{
Antônio Jorge Parga Silva ${ }^{1}$, Francisco Antonio Rocco Lahr ${ }^{2}$, André Luis Christoforo ${ }^{3, *}$, \\ Túlio Hallak Panzera ${ }^{3}$
}

\author{
${ }^{1}$ Department of Civil Construction, Federal Center of Technological Education of Maranhão, São Luis, 65030-000, Brazil \\ ${ }^{2}$ Department of Structural Engineering, University of São Paulo (EESC/USP), São Carlos, 13566-590, Brazil \\ ${ }^{3}$ Department of Mechanical Engineering, Federal University of São João del-Rei (UFSJ), São João del-Rei, 36307-352, Brazil
}

\begin{abstract}
The composites of natural fibers are products known in several parts of the world, however their utilization is relatively restrict due to the lack of information concerning their properties and structures. Lignocellulosic fibers present high length/thickness relation, which contributes to the biodegradation and continuity of the ecological cycle. Such fibers present low density and enable a lower cost in composites manufacture, playing an important role in the definition of their physical and mechanical properties. The cane bagasse is a residue derived from sugar cane, a commercially important product in Brazil, with a high concentration of fibers, high content of lignin, which is a factor of environmental impact, with future perspectives of use. The present paper aims to evaluate the density of cane bagasse as composites of long particles and their internal adhesion, as well as to verify their temperature until decomposition and suggest their possible future utilization. The requisites of this product in terms of limit values for the properties of OSB are defined by EN-300/2002 standard.
\end{abstract}

Keywords Composites, OSB, Sugar Cane Bagasse

\section{Introduction}

The reutilization of natural organic residues to obtain an applicable product is a very useful practice that generates many advantages in the evaluation of social areas, expanding baselines for economic applications, with a low cost product which is ecological and far less polluting, in order to create a country's sustainable development.

Alternatively to the use of organic waste for use in buildings and other compounds are distinguished OSB (Oriented Strand Board), made up of wooden panels or comparable (long, large and fine particles) agglutinated with a resin and compressed in layers.

Generally, on its external layers the OSB has its flakes arranged longitudinally in relation to the length of the board, while in the intermediate layers they are arranged perpendicularly or randomly distributed, as illustrated in Figure 1.

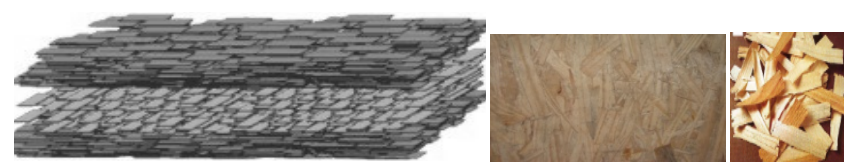

Figure 1. Directed layers, long particles and OSB panels in the market. Source:[1]

* Corresponding author:

alchristoforo@yahoo.com.br (André Luis Christoforo)

Published online at http://journal.sapub.org/ijme

Copyright (C) 2012 Scientific \& Academic Publishing. All Rights Reserved
Because it is a composite material, the choice of factors and levels associated with these in the development of OSB provide for the development and study of a series of surveys.

Zhow[2] asserts that the direction of the particles causes a 40 to $50 \%$ increase in MOR and MOE, respectively, parallel to the direction in relation to the particle panels that are distributed randomly.

According to[3], the angle formed in the particle distribution in the layer is highly dependent on the height of the particles falling, with lower heights providing better direction as a consequence of forming a smaller angle.

Also with respect to other works OSB panels can be mentioned, as[4], studied the Poisson's ratio by varying the orientation of the chips, and[5], using a method based on image analysis for the determining the modulus of elasticity (MOE) and rupture (MOR),[6], investigated the influence of pressure levels on the mechanical performance of composite OSB,[7] and evaluated the mechanical properties of panels composed of wavy wires,[8], using the compounds in OSB manufacture of furniture and others.

In the OSB panels the long particles are bonded with the types of resin: phenol-formaldehyde, melamine-ureaformaldehyde and polyurethane, all of which are ligaments resistant to moisture and therefore the panel, which is pressed under medium or high temperature, increases its mechanical resistance and hardness.

According to[9], the São Carlos Chemistry Institute, São Paulo University (USP), bestowed an important national contribution by developing a polyurethane resin that has 
many advantages, such as: manipulation in room temperature, water resistance, mechanical resistance, moreover it resulted from a renewable natural source, whose raw material (mamona) can adapt climatically throughout the entire national territory.

AraújO[10] performed a series of tests in order to determine the characteristics of various polyurethane resin compositions based on mamona oil. With regards to the thermal stability of the polyurethanes, by means of thermal analysis that close to $220^{\circ} \mathrm{C}$ there is only a small mass loss, which evidences thermal stability of the resins up to this temperature.

Claro Neto[11] determined the physical-chemical properties of the polyurethane resin polymer, bi-component, derived from mamona oil. He verified the thermal component of the polymer between two components in his research, verifying that the polymer's decomposition curve has two decomposition stages; the first stage beginning at $300^{\circ} \mathrm{C}$ and the second one at $400^{\circ} \mathrm{C}$.

OSB panels are usually made with wood chips oriented[1]. In order to strengthen, other materials may also be used, among them, bagasse from sugar cane. Brazil is the largest producer of sugar cane worldwide and the residues from this product are generated in equal proportions, moreover reutilization of the components of this vegetal biomass is extremely important environmentally and economically.

According to[12], sugar cane bagasse is composed of fibers, medule, fine particles and soluble materials, with the in natura bagasse chemically composed of 44,5\% of lignocellulosic fibers; $50 \%$ of moisture; $2,5 \%$ of soluble solids in water and 3,0\% of ash.

Han and $\mathrm{Wu}[13]$ compared the properties of the rind of the sugar cane against pine wood flakes in the manufacture of structural composite and verified a chemical similarity of the more external part of the cane with the wood, however with less homogeneity, lesser thermal stability (TG and DSC) and resistance to traction slightly superior to the wooden slivers for structural effects.

The use of sugarcane bagasse in compounds intended for most of the cement matrix, which may be mentioned the work of[14],[15],[16],[17],[18].

In view of the expounded elucidation regarding the study of developed materials of sugar cane derivates, or to be more precise, of its residue, it is very relevant in environmental, social economic and technological aspects.

The present paper evidences originality, interest and the immense field of application for the sugar cane residue as bagasse, in which the residue is tested without separating the denser fibers, less dense ones and the medulla, aiming at conveying more advantage, aggregated value and economic impact to the product, being investigated the response variables: moisture, density, swelling, internal compliance and modulus of elasticity and rupture strength.

To assess sugar cane bagasse without separating its composition; fibers, medulla and fine particles, randomly verifying its pressing temperature until decomposing, assessing its properties as long and directed particle composites (OSB) and eventual utilization as sustainable product, corroborating as one of the investment solutions for new products and future technologies.

\section{Materials and Methods}

The material used in this evaluation was the sugar cane residue, commonly known as "bagasse" originating from the mills located near the city of São Carlos, SP, Brazil. It was evaluated as composite, which is particulate and resin composites. The resin employed was polyurethane based on mammon oil, type bi-component and the reaction time was of 25 minutes. The resin with pre-polymer I201 will be used with 1:2 feature to produce the panels, with one part of pre-polymer based on di-isocyanate and 2 parts of polyol. These resin composites were donated by KEHL Chemical Industry of São Carlos-SP. One of the resins is done by cold curing process, which can be accelerated by increasing the temperature up to $120^{\circ} \mathrm{C}$ without losing its properties. Because the group of derivatives usually applies this temperature, $90^{\circ} \mathrm{C}$ was chosen, thus generating less energy in the fabrication process of panels[1].

\subsection{Thermogravimetry (TG) and Differential Thermal Analysis (DTA)}

A simultaneous thermal balance TG-DTA, brand NETZSCH, model STA 409 Cell (Figure 2) was employed for this analysis, with a heating rate of $10^{\circ} \mathrm{C} / \mathrm{min}$. owing to the fact that this heating ratio promotes a better resolution curve standard in nitrogen atmosphere.

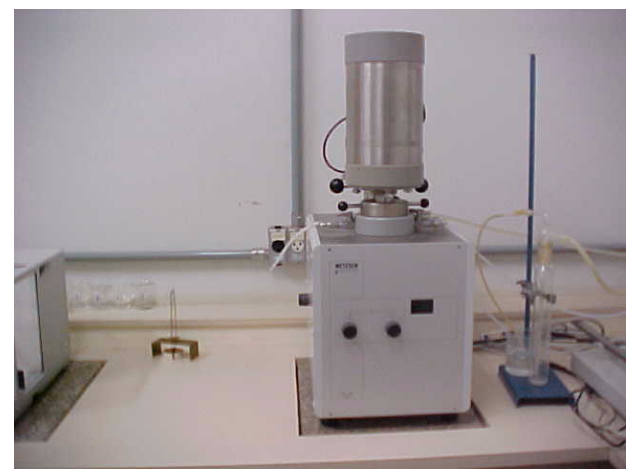

Figure 2. NETZSCH Equipment, model STA 409 Cell-Thermogravimetric analysis

\subsection{Treatment}

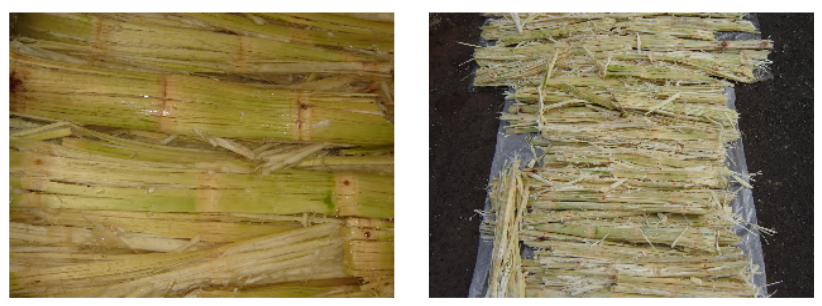

Figure 3. Material treated in water and sun dried for preliminary drying

The bagasse is submersed in room temperature water to 
remove saccharose and impurities, afterwards it is removed and dried, a shown in Figure 3.

\subsection{Drying}

The artificial drying process is done in heater for 16 hours at $60^{\circ} \mathrm{C}$ temperature, where it is checked for possible anomalies, since above this temperature there is water loss that could cause disequilibrium to its basic structural form. Immediately after treatment and drying it is prepared for particulate obtainment by cutting (Figure 4) it to mean length of $14 \mathrm{~cm}$.
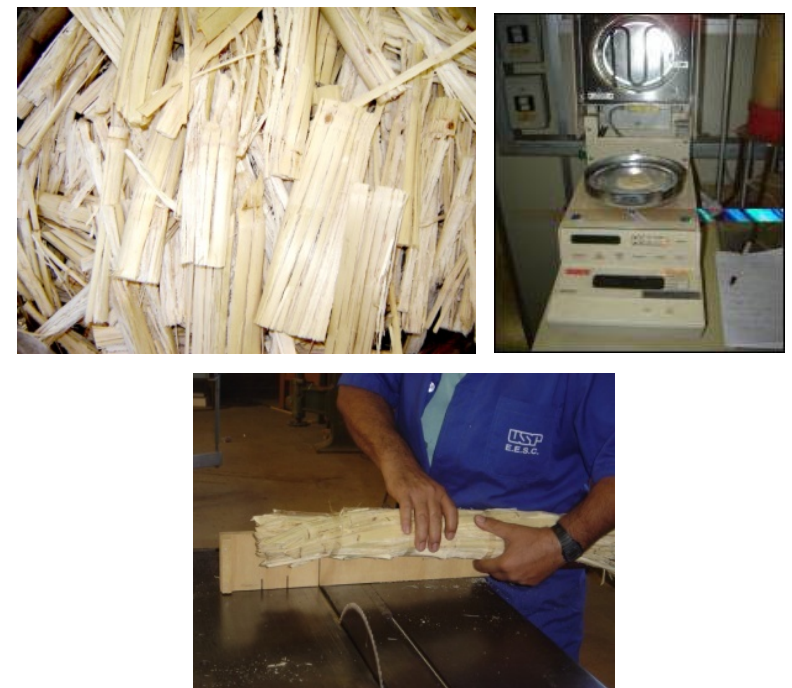

Figure 4. Bagasse after being dried in heater, test equipment, solid percentage and slicing of sugar cane bagasse

\subsection{Mixture Particulate Direction and Pressing}

The mixing process is relative to the degree of residue compaction and follows the standard guidelines commonly used to industrially manufacture oriented strand board (OSB). Cane bagasse offers a wide range of applications owing to its low density fiber and low cost. In the present paper for the production mixture, a mammon based oil polyurethane resin was employed at a proportion of 1:2, pre-polymer/polyol and cane-bagasse type residue in compaction proportion and intended density, respectively.

Subsequent to the resin application, the long particles were placed in a particle orienter to divide the layers. Such layers are divided in external and internal layers. The external layers imperatively have the same orientation, while the internal ones can be oriented or not, as illustrated in Figure 5.

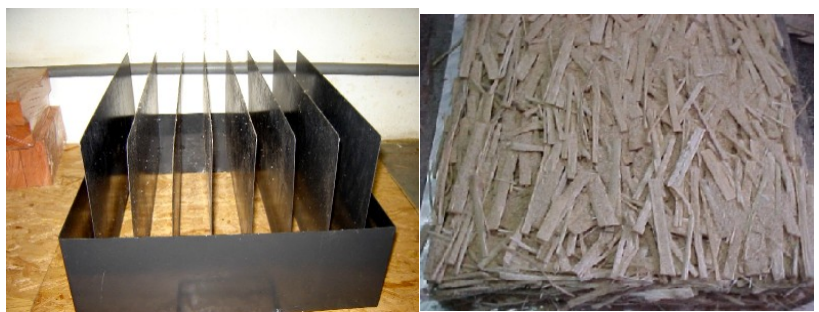

Figure 5. Large particle orienter developed in LaMEM-SET and layers of oriented particles of cane bagasse
From preparation time to particle orientation, it takes 12 to 15 minutes, initial reaction time of resin or gel time of mammon based resin. After orientation, the long particles are pre-pressed aiming to uniformly distribute layer compaction and then are subjected to $90^{\circ} \mathrm{C}$ temperature to be pressed for 10 minutes in a hydraulic type press brand Marconi MA-98/50, Figure 6. This temperature is responsible for acceleration of the resin cure and accountable for thermal standards of the cane bagasse.

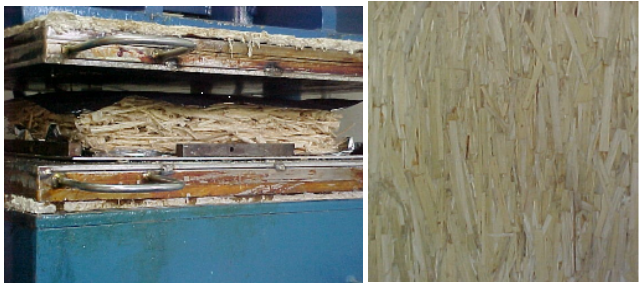

Figure 6. Long particles in Marconi MA-98/50 hydraulic press and definitive panel

After pressing, a panel is formed when each one is positioned vertically and maintained in this position for 30 days. This time is necessary for the panels to stabilize the pressing and ambient temperature, thus complementing the resin cure and correlating the moisture on the sides and center of the board.

The boards were squadded into $400 \mathrm{~mm} \times 400 \mathrm{~mm} \times 13 \mathrm{~mm}$, subsequently they were cut as samples for tests in agreement with standard EN/300[19].

\subsection{Moisture Test}

The samples with a minimum weight of $20 \mathrm{~g}$ must be removed, their form and dimensions are not important. However, they must not possess free particles.

Initially, the samples should be weighed and then placed in a heater at a temperature of $\left(103^{ \pm} 2\right)^{\circ} \mathrm{C}$ until they reach a constant mass.

Afterwards, it must cool to room temperature, weighed again and the moisture ratio calculated by Equation 1:

$$
H=\frac{m_{v}-m_{S}}{m_{S}} \cdot 100
$$

$\mathrm{H}=$ humidity $(\%)$;

$\mathrm{ms}=$ dry mass $(\mathrm{g})$;

$\mathrm{mv}=$ green or humid mass $(\mathrm{g})$.

\subsection{Density Tests}

The square samples must be removed and the sides should measure nominally $50 \mathrm{~mm}$ and conditioned up to a constant mass to a relative moisture of $\left(65^{ \pm} 5\right) \%$ and a temperature of $\left(20^{ \pm} 2\right)^{\circ} \mathrm{C}$. Constant mass is when the results of the successive weighing, performed with at least $24 \mathrm{~h}$. interval, do not differ more than $0,1 \%$ in relation to the sample mass.

The samples should initially be weighed and their $t$ thickness measured at the point they meet diagonally. b1 and b2 should be measured at two points, parallel to the edge of the sample, along the lines that pass through the center of the opposing edges. Density is calculated by Equation 2: 


$$
\rho=\frac{m}{b_{1} \cdot b_{2} \cdot t} \cdot 10^{6}
$$

$\mathrm{m}=\operatorname{mass}(\mathrm{g})$;

$\mathrm{t}=$ thickness $(\mathrm{mm})$;

$\mathrm{b} 1$ and $\mathrm{b} 2=$ dimension of edges $(\mathrm{mm})$.

\subsection{Test of Swelling in Thickness}

To determine the swelling in thickness, after immersion of the panels in distilled water for 24 hours, the square format samples with edges of $(50 \pm 1) \mathrm{mm}$ must be removed.

The thickness of the samples must be diagonally measured at the intersection before and after it is immersed in clean water with $\mathrm{pH} 7 \pm 1$, at a temperature of $20 \pm 1 \mathrm{oC}$ and must remain submerged in $25 \pm 5 \mathrm{~mm}$ of water for 24 hours. The thickness swelling in percentage is calculated by Equation 3:

$$
G_{t}=\frac{t_{2}-t_{1}}{t_{1}} \cdot 100
$$

$\mathrm{Gt}=$ thickness swelling $24 \mathrm{~h}(\%)$;

$\mathrm{t} 1=$ initial thickness $(\mathrm{mm})$;

$\mathrm{t} 2$ = final thickness after $24 \mathrm{~h}(\mathrm{~mm})$.

\subsection{Internal Adhesion}

For internal adhesion (IA) of the panels, the square shaped samples must be removed with edges measuring $(50 \pm 1)$ $\mathrm{mm}$.

Metal supports are fastened on both sides of the samples, subsequently they undergo traction in opposite directions so that they sever. Internal Adhesion is calculated by Equation 4:

$$
I A=\frac{F_{\max }}{a \cdot b}
$$

Where,

$\mathrm{IA}=$ Internal adhesion $(\mathrm{MPa})$

Fmax $=$ Maximum force $(\mathrm{N})$;

$\mathrm{a}=$ sample length $(\mathrm{mm})$;

$\mathrm{b}=$ sample width $(\mathrm{mm})$;

$\mathrm{A}($ Adhesive area $)=\mathrm{a} \times \mathrm{b}$.

\subsection{Modulus of Elasticity and Modulus of Rupture in Static Bending Tests}

To determine modulus of elasticity (Em) and modulus of rupture $(\mathrm{Fm})$ in static bending tests, rectangular shaped samples must to used, with $(50 \pm 1) \mathrm{mm}$ midth (b). The length (11) should be 20 times the nominal thickness plus $50 \mathrm{~mm}$.

The specimens should be conditioned up to constant weight, under relative moisture of $(65 \pm 5) \%$ and a temperature of $(20 \pm 2) \mathrm{oC}$, considering that constant weight is obtained when the results of two successive weighing, performed with at least $24 \mathrm{~h}$ of interval, do not differ more than $0,1 \%$ in relation to the initial sample weight.

The Modulus of Elasticity in bending strength (Em) is calculated by Equation 5. Each set of samples taken from the same panel gives the mean value to Em:

$$
E_{m}=\frac{l_{1}^{3} \cdot\left(F_{2}-F_{1}\right)}{4 \cdot b \cdot t^{3} \cdot\left(a_{2}-a_{1}\right)}
$$

$11=$ distance between the support centers $(\mathrm{mm})$;

$\mathrm{b}=$ sample width $(\mathrm{mm})$;

$\mathrm{t}=$ sample thickness $(\mathrm{mm})$;

$\mathrm{F} 2-\mathrm{F} 1=$ force increase, Newton, in the rectilinear section of the force-arrow curve, where F1 should be about $10 \%$ and F2 about $40 \%$ of the rupture force;

$\mathrm{a} 2-\mathrm{a} 1=$ increase of corresponding arrow F2 $-\mathrm{F} 1$.

The fm value of each sample, given in $\mathrm{N} / \mathrm{mm} 2$, is calculated by Equation 6 . Each set of samples taken from the same panel gives the mean value to fm:

$$
f_{m}=\frac{3 \cdot F_{\text {max }} \cdot l_{1}}{2 \cdot b \cdot t^{2}}
$$

Fmax $=$ Rupture force $(\mathrm{N})$;

$11=$ distance between support centers $(\mathrm{mm})$;

$\mathrm{b}=$ sample width $(\mathrm{mm})$;

$\mathrm{t}=$ sample thickness $(\mathrm{mm})$.

2.10. Internal Adhesion in Boiling Water

The test in boiling water is employed to verify conformity in order to control adhesion quality obtained through such approved adhesion methods. This standard is applied following the procedures:

Place the samples in boiling water and remove after $(120 \pm 5)$ minutes, afterwards remove them and immerse in water $(20 \pm 5)^{\circ} \mathrm{C}$ for $(60 \pm 5)$ minutes. Place the samples with their sides in vertical position, with at least $15 \mathrm{~mm}$ from each other, from the sides and the bottom of the recipient.

Remove the samples and dry them with absorbing paper, then place them in a heater for $(70 \pm 2)^{\circ} \mathrm{C}$.

Remove samples, dry them with absorbent paper and place them in heater.

The samples should be placed horizontally in air circulating heater capable of maintaining interior temperature at $(70 \pm 2)^{\circ} \mathrm{C}$ during $(960 \pm 15)$ minutes.

Afterwards, remove the samples from the heater and allow them to cool to room temperature, bind the boards on the sides of the samples and if the surface is wrinkled or uneven, it can be corrected prior to binding the test boards by polishing with sandpaper.

\section{Results}

\section{Thermal characteristics}

In the analysis of thermal characteristics of the sugar cane bagasse is taken into consideration as well as the polyurethane mammon based resin applied.

For the cane bagasse a thermogravimetric decomposition curve was set up, varying from room temperature up to $300^{\circ} \mathrm{C}$, as seen in Figure 7.

Suitable behavior was verified from room temperature up to $60^{\circ} \mathrm{C}$, higher than this temperature there is a water loss up to $75^{\circ} \mathrm{C}$, after this point the beginning of an ebullition reaction at around $100^{\circ} \mathrm{C}$ is seen, afterwards water loss of 
decomposition near $125^{\circ} \mathrm{C}$ begins, hence occurring the start of decomposition of the bagasse structure at $200^{\circ} \mathrm{C}$ and from this temperature the process of total burning of the residue initiates.

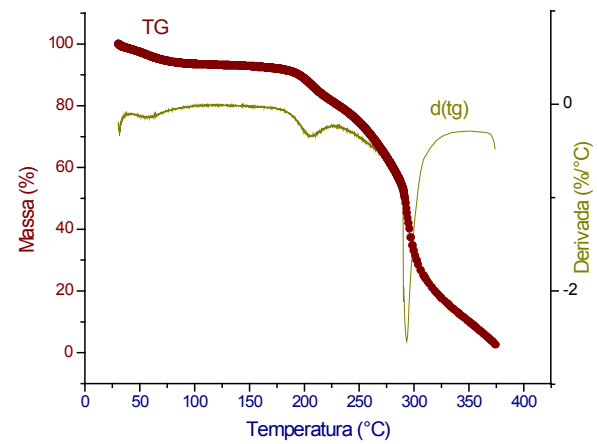

Figure 7. Thermogravimetric decomposition curve of the sugar cane bagasse

Based on this fundamental information we can define the temperature at $90^{\circ} \mathrm{C}$ for long particle pressing, because it is within the acceptable thermal standard for the bagasse/resin ratio.

\section{Moisture and density ratio}

The Table 1 shows the results of the moisture and density ratio of cane bagasse with $10 \%$ of polyurethane mammon based resin.

Table 1. Moisture and density ratio of cane bagasse composite

\begin{tabular}{|c|c|c|c|c|c|c|}
\hline \multirow[t]{2}{*}{ Specimens } & Volume & $\mathbf{m v}$ & ms & H & pap & $\rho a p ~ v$ \\
\hline & $\left(\mathrm{cm}^{3}\right)$ & (g) & (g) & $(\%)$ & $\left(\mathrm{g} / \mathrm{cm}^{3}\right)$ & $\left(\mathrm{g} / \mathrm{cm}^{3}\right)$ \\
\hline 1 & 34,1 & 20,5 & 19,1 & 7,3 & 0,56 & 0,60 \\
\hline 2 & 34,1 & 20,7 & 19,2 & 7,6 & 0,56 & 0,61 \\
\hline 3 & 33,7 & 20,4 & 19,1 & 7,1 & 0,57 & 0,61 \\
\hline 4 & 33,4 & 20,3 & 18,9 & 7,2 & 0,57 & 0,61 \\
\hline 5 & 33,7 & 20,4 & 19,0 & 7,5 & 0,56 & 0,61 \\
\hline 6 & 34,0 & 20,6 & 19,1 & 7,4 & 0,56 & 0,60 \\
\hline 7 & 33,3 & 20,3 & 18,9 & 7,6 & 0,57 & 0,61 \\
\hline 8 & 33,5 & 20,4 & 19,0 & 7,2 & 0,57 & 0,61 \\
\hline 9 & 33,0 & 20,3 & 19,0 & 7,0 & 0,57 & 0,61 \\
\hline 10 & 33,7 & 20,4 & 19,0 & 7,4 & 0,56 & 0,61 \\
\hline 11 & 34,3 & 20,8 & 19,3 & 7,6 & 0,56 & 0,61 \\
\hline 12 & 33,4 & 20,4 & 19,1 & 6,9 & 0,57 & 0,61 \\
\hline Average & 33,7 & 20,4 & 19,0 & 7,3 & 0,57 & 0,61 \\
\hline StDev & 0,4 & 0,1 & 0,1 & 0,2 & 0,00 & 0,00 \\
\hline V.C.(\%) & 1,1 & 0,7 & 0,6 & 3,3 & 0,70 & 0,57 \\
\hline
\end{tabular}

It can be concluded that apparent density at $12 \%$ moisture obtained a value of $0,57 \mathrm{~g} / \mathrm{cm}^{3}$ with relative moisture at around $7 \%$, a favorable result for the production of orientated OSB panels.

\section{Swelling in Thickness}

The Table 2 shows the results of the swelling in Thickness test by 24 hours.
Table 2. Swelling in Thickness test by 24 hours

\begin{tabular}{cccc}
\hline Specimens & $\mathbf{t}_{\mathbf{1}}(\mathbf{m m})$ & $\mathbf{t}_{\mathbf{2}}(\mathbf{m m})$ & $\mathbf{G} \mathbf{( \% )}$ \\
\hline 1 & 12,2 & 14,3 & 17,2 \\
2 & 13,0 & 14,5 & 11,5 \\
3 & 13,0 & 14,4 & 10,8 \\
4 & 13,1 & 14,5 & 10,7 \\
5 & 12,2 & 13,7 & 12,3 \\
6 & 12,8 & 15,0 & 17,2 \\
7 & 13,2 & 14,7 & 11,4 \\
8 & 13,0 & 13,9 & 6,9 \\
9 & 12,4 & 13,9 & 12,1 \\
10 & 13,1 & 14,7 & 12,2 \\
11 & 12,6 & 13,9 & 10,3 \\
12 & 12,4 & 14,1 & 13,7 \\
\hline Average & 12,8 & 14,3 & 12,2 \\
StDev & 0,4 & 0,4 & 2,8 \\
V.C.(\%) & 2,9 & 2,8 & 23,4 \\
\hline
\end{tabular}

The thickness swelling test $24 \mathrm{~h}$ for OSB shows values from 12 to $25 \%$. Based on such information, in relation to thickness swelling the composite of cane bagasse long particles presented mean value of $12.2 \%$, which is within acceptable standard standards.

\section{Internal Adhesion}

The Table 3 shows the results of the internal adhesion tests of cane bagasse with $10 \%$ resin.

Table 3. Internal adhesion of cane bagasse with $10 \%$ resin

\begin{tabular}{cccc}
\hline Specimens & $\mathbf{F}_{\mathbf{m a x}}(\mathbf{N})$ & $\mathbf{A}\left(\mathbf{m m}^{\mathbf{2}}\right)$ & $\mathbf{I A ( M P a )}$ \\
\hline 1 & 565 & 2500 & 0,23 \\
2 & 486 & 2500 & 0,19 \\
3 & 534 & 2500 & 0,21 \\
4 & 676 & 2500 & 0,27 \\
5 & 686 & 2500 & 0,27 \\
6 & 451 & 2500 & 0,18 \\
7 & 462 & 2500 & 0,18 \\
8 & 680 & 2500 & 0,27 \\
9 & 678 & 2500 & 0,27 \\
10 & 690 & 2500 & 0,28 \\
11 & 630 & 2500 & 0,25 \\
12 & 575 & 2500 & 0,23 \\
\hline Average & 593 & 2500 & 0,24 \\
StDev & 93 & 0 & 0,04 \\
V.C.(\%) & 16 & 0 & 15,63 \\
\hline
\end{tabular}

Internal adhesion is influenced by the particles/resin relation and its mixing process. However, this test obtained a mean internal adhesion value of $0,24 \mathrm{MPa}$, Table 5 . The value obtained for internal adhesion in OSB by EN300[19] is equal to or higher than $0,28 \mathrm{MPa}$. On the other hand, this result is attributed to the fact that mixing is manual and takes into consideration losses due to industrial processes. Thus, 
we suggest this as an acceptable assessment for future studies.

\section{Internal adhesion in boiling water (Cyclic test)}

The Table 4 shows the results of the internal adhesion after boiling water test.

Table 4. Internal adhesion after boiling water test

\begin{tabular}{cccc}
\hline Specimens & $\mathbf{F}_{\mathbf{m a x}}(\mathbf{N})$ & $\mathbf{A}\left(\mathbf{m m}^{\mathbf{2}}\right)$ & $\mathbf{I A ( M P a )}$ \\
\hline 1 & 350 & 2500 & 0,14 \\
2 & 289 & 2500 & 0,12 \\
3 & 410 & 2500 & 0,16 \\
4 & 370 & 2500 & 0,15 \\
5 & 361 & 2500 & 0,14 \\
6 & 382 & 2500 & 0,15 \\
7 & 371 & 2500 & 0,15 \\
8 & 528 & 2500 & 0,21 \\
9 & 317 & 2500 & 0,13 \\
10 & 644 & 2500 & 0,26 \\
11 & 437 & 2500 & 0,17 \\
12 & 339 & 2500 & 0,14 \\
\hline Average & 400 & 2500 & 0,16 \\
StDev & 98 & 0 & 0,04 \\
V.C. (\%) & 25 & 0 & 24,60 \\
\hline
\end{tabular}

Internal adhesion for boiling water test in thickness between 10 and $18 \mathrm{~mm}$ varies from 0,13 to $0,14 \mathrm{MPa}$. In this paper an internal adhesion value in boiling water of 0,16 MPa was observed, in a bagasse/resin composition with $10 \%$ mammon based resin at pressing temperature of $90^{\circ} \mathrm{C}$. Thus, concluding that this bagasse/resin relation obtained superior standard values.

\section{Modulus of Elasticity and Modulus of Rupture}

The Table 5 shows the results of the modulus of elasticity in bending tests for condition: longitudinal fibers with $10 \%$ of pressed resin at temperature of $90^{\circ} \mathrm{C}$.

Table 5. Results of bending tests: longitudinal fibers with $10 \%$ of pressed resin at temperature of $90^{\circ} \mathrm{C}$

\begin{tabular}{|c|c|c|c|c|c|c|c|}
\hline Specimens & I (mm) & $F_{\max }(N)$ & $\begin{array}{ll}F_{1} & F_{2}\end{array}$ & $\mathbf{a}_{1}$ & $\mathbf{a}_{2}$ & $\mathrm{~F}_{\mathrm{m}}(\mathrm{MPa})$ & $E_{m}(\mathbf{M P a})$ \\
\hline 1 & 260 & 730 & $73,0292,0$ & 0,70 & 2,32 & 35 & 5675 \\
\hline 2 & 260 & 870 & $87,0348,0$ & 0,58 & 2,53 & 41 & 5609 \\
\hline 3 & 260 & 908 & $90,8363,2$ & 0,70 & 2,54 & 41 & 5731 \\
\hline 4 & 260 & 855 & $85,5342,0$ & 0,62 & 2,31 & 38 & 5796 \\
\hline 5 & 260 & 634 & $63,4253,6$ & 0,56 & 2,02 & 29 & 5100 \\
\hline 6 & 260 & 785 & $78,5314,0$ & 1,04 & 2,89 & 37 & 5349 \\
\hline 7 & 260 & 860 & $86,0344,0$ & 1,25 & 3,14 & 39 & 5336 \\
\hline 8 & 260 & 638 & $63,8255,2$ & 0,63 & 2,20 & 29 & 4873 \\
\hline 9 & 260 & 737 & $73,7294,8$ & 0,78 & 2,52 & 33 & 4872 \\
\hline 10 & 260 & 741 & $74,1296,4$ & 0,69 & 2,31 & 35 & 5642 \\
\hline 11 & 260 & 685 & $68,5274,0$ & 0,67 & 2,31 & 31 & 4898 \\
\hline 12 & 260 & 715 & $71,5286,0$ & 0,72 & 2,56 & 35 & 5004 \\
\hline Average & 260 & 780 & $78,0311,9$ & 0,76 & 2,50 & 36 & 5371 \\
\hline StDev & 0 & 101 & $10,140,6$ & 0,23 & 0,34 & 5 & 359 \\
\hline V.C.(\%) & 0 & 13 & $13,0 \quad 13,03$ & 30,56 & 13,81 & 13 & 7 \\
\hline
\end{tabular}

In agreement with standard EN-300[19], modulus of rupture in longitudinal bending, in thickness between 10 and $18 \mathrm{~mm}$ requires values from 18 to $28 \mathrm{MPa}$ and modulus of elasticity from 2500 to $4800 \mathrm{MPa}$. In the work, to panels with $10 \%$ mammon based resin, $90^{\circ} \mathrm{C}$ pressing temperature, $\mathrm{f}_{\mathrm{m}}=36 \mathrm{MPa}$ and $\mathrm{E}_{\mathrm{m}}=5371 \mathrm{MPa}$ were obtained. Requirements of EN-300[19] were reached.

The Table 6 shows the results of the modulus of elasticity in bending tests for condition: transversal to fibers with $10 \%$ of pressed resin at temperature of $90^{\circ} \mathrm{C}$.

Table 6. Results of bending tests: Transversal fibers with $10 \%$ of pressed resin at temperature of $90^{\circ} \mathrm{C}$

\begin{tabular}{cccccccc}
\hline Specimens & $\mathbf{I}_{\mathbf{1}}(\mathbf{m m})$ & $\mathbf{F}_{\mathbf{1}}$ & $\mathbf{F}_{\mathbf{2}}$ & $\mathbf{a}_{\mathbf{1}}$ & $\mathbf{a}_{\mathbf{2}}$ & $\mathbf{F}_{\mathbf{m}}(\mathbf{M P a})$ & $\mathbf{E}_{\mathbf{m}}(\mathbf{M P a})$ \\
\hline 1 & 260 & 27,0 & 108,0 & 2,0 & 6,0 & 13 & 826 \\
2 & 260 & 25,9 & 103,6 & 1,4 & 5,0 & 12 & 815 \\
3 & 260 & 26,8 & 107,2 & 1,3 & 4,5 & 13 & 1066 \\
4 & 260 & 25,5 & 102,0 & 1,4 & 5,1 & 12 & 807 \\
5 & 260 & 31,6 & 126,4 & 1,8 & 6,7 & 14 & 746 \\
6 & 260 & 39,2 & 156,8 & 1,9 & 7,2 & 18 & 872 \\
7 & 260 & 33,5 & 134,0 & 1,6 & 5,9 & 15 & 903 \\
8 & 260 & 28,1 & 112,4 & 1,5 & 5,8 & 13 & 793 \\
9 & 260 & 29,2 & 116,8 & 1,5 & 5,9 & 14 & 821 \\
10 & 260 & 27,1 & 108,4 & 1,4 & 5,8 & 13 & 755 \\
11 & 260 & 29,7 & 118,8 & 1,5 & 5,9 & 14 & 841 \\
12 & 260 & 32,1 & 128,4 & 1,8 & 6,6 & 15 & 779 \\
\hline Average & 260 & 29,6 & 118,6 & 1,6 & 5,9 & 14 & 835 \\
StDev & 0 & 3,9 & 15,8 & 0,2 & 0,7 & 2 & 85 \\
V.C. & 0 & 13,3 & 13,3 & 13,7 & 12,6 & 12 & 10 \\
\hline & & & & & & &
\end{tabular}

In transversal direction, to panels with 10 to $13 \mathrm{~mm}$ thickness, EN-300 requires $\mathrm{f}_{\mathrm{m}}$ between 9 to $15 \mathrm{MPa}$ and $\mathrm{E}_{\mathrm{m}}$ between 1200 and $1900 \mathrm{MPa}$. In this work, to the studied panels, $\mathrm{f}_{\mathrm{m}}=14 \mathrm{MPa}$ and $\mathrm{E}_{\mathrm{m}}=835 \mathrm{MPa}$ were obtained.

The low value of the modulus of elasticity is probably attributed to the process of mixture, the pressure and temperature. In the next studies these variables will be more carefully controlled in order to confirm the cited hypothesis.

\section{Conclusions}

Sugar cane bagasse possesses a broad thermal baseline in its use of resins and other applications, which ranges from room temperature up to $150^{\circ} \mathrm{C}$, with decomposition beginning at $200^{\circ} \mathrm{C}$. Results indicate to application of cane bagasse with long particles, evidencing high, medium and low density.

The values of modulus of rupture and modulus of elasticity in longitudinal direction reached the method requeriments. In transversal direction, only the modulus of rupture reached the method requeriments. Modulus of elasticity values can be incresed by a more care control of mixing process and pressing temperatures.

Internal adhesion of the particulate with $10 \%$ of polyurethane mammon based resin is considered satisfactory, 
notwithstanding the mix process was manual.

Since Brazil is the biggest worldwide producer of sugar cane residue, it is considerably favorable for this type of particulate with this kind of raw material and technique.

\section{REFERENCES}

[1] A. J. P. Silva. "Aplicação de partículas longas e orientadas de bagaço de cana-de-açúcar na produção de painel particulado similar ao OSB". Tese (Doutorado). Escola de Engenharia de São Carlos da Universidade de São Paulo, 2006.

[2] D. Zhow. "A estudy of oriented structural board made from hybrid poplar. Phisical and mechanical properties of OSB". Holz Als Roh Und Werkstoff, Berlin, v. 48, n. 7-8, p. 293-296, 1990.

[3] S. Suzuki, K. Takeda. "Production and properties of Japanese oriented strand board I: effect of strand length and orientation on strength properties of sugi oriented strand board". Japan Wood Science, Tokyo, v. 46, p. 289-295. 2000.

[4] W. Thomas. "Poisson's ratios of an oriented strand board". Wood Sci Technol, 37, pp. 259-268, 2003.

[5] T. Nishimura, M. P. Ansell, N. Ando. "The relationship between the arrangement of wood strands at the surface of OSB and the modulus of rupture determined by image analysis". Wood Sci Technol, 35 (6), pp. 555-562, 2003.

[6] G. Painter, H. Budman, M. Pritzker. "Prediction of oriented strand board properties from mat formation and compression operating conditions". Part 2: MOE prediction and process optimization. Wood Sci Technol, 40 (4), pp. 291-307, 2006.

[7] V. Yadama, M. P. Wolcott, L. V. Wolcott. "Elastic properties of wood-strand composites with undulating strands". Compos Part A: Appl Sci Manuf, 37 (3), pp. 385-392, 2006.

[8] M. Rebollar, R. Perez, R. Vidal. "Comparison between oriented strand boards and other wood-based panels for the manufacture of furniture". Mater Des, 28 (3), pp. 882-888, 2008.

[9] J. M. H. Jesus. "Estudo do adesivo poliuretano à base de mamona em madeira laminada colada(MLC)". São Carlos, 2000, 106p. Tese de Doutorado - Ecla de Engenhria de São Carlos, Universidade de São Paulo.
[10] L. C. R. Araújo. "Caracterização química e mecânica de poliuretanas elastoméricas baseadas em materiais oleoquímicos". São Carlos, 1992. Dissertação de Mestrado Instituto de Física e Química de São Carlos. Universidade de São Paulo.

[11] S. Claro Neto. "Caracterizações físico-químicas de um poliuretano derivado de óleo de mamona utilizado para implantes ósseos". São Carlos, 1997. 127p Tese de Doutorado - Instituto de Química de São Carlos, Universidade de São Paulo.

[12] M. A. E. Santana, D. E. Teixeira. "Uso do bagaço de cana-de-açúcar na confecção de chapas de aglomerados”. In: Congresso Florestal Brasileiro, 7; Congresso Florestal Pan-americano, 1. Curitiba, 1993. Anais. São Paulo: SBS/SBEF, p. 667-672, 1993.

[13] G. Han, Q. Wu. "Comparative properties of sugarcane rind and wood strands for structural composite manufacturing". Forest Products Journal 54(12): p. 283-288, December/2004.

[14] M. C. Mesa Valenciano. "Incorporação de resíduos agroindustriais e seus efeitos sobre as características físico-mecânicas de tijolos de solo melhorado com cimento". Dissertação (Mestrado) - Faculdade de Engenharia Agrícola, Universidade de Campinas, Campinas, 1999.

[15] J. F. M. Hernández, B. Middendorf, M. Gehrke, H. Budelmann. "Use of wastes of the sugar industry as pozzolana in lime-pozzolana binders: study of the reaction". Cement and Concrete Research, v. 28, n. 11, p. 1525-1536, 1998.

[16] L. K. Aggarwal. "Bagasse-reinforced cement composites". Cement and Concrete Composites, v. 17, n. 2, p. 107-112, 1995.

[17] C. R. Sarmiento, W. J. Freire. "Argamassa de cimento e areia combinada com fibras de bagaço de cana-de-açúcar". Engenharia Agrícola, v. 17, n. 2, p. 1-8, 1997.

[18] C. Y. Kawabata. "Aproveitamento de cinzas da queima de resíduos agroindustriais na produção de compósitos fibrosos e concreto leve para a construção rural". Tese (Doutorado) Faculdade de Zootecnia e Engenharia de Alimentos da Universidade de São Paulo, Pirassununga, 2008.

[19] European Committee For Standardization. European Standard - EN 300. Aglomerado de partículas de madeira longas e orientadas (OSB) - Definições, classificação e especificações. Portugal, 2002. 